\title{
Challenges of Introducing Islamic Banking to the Global Financial Market
}

\author{
Tahmoures A. Afshar \\ Professor of Finance, School of Business, Woodbury University \\ 7500 N. Glenoaks Blvd., Burbank, California 91504-1052, USA \\ Majed R. Muhtaseb (Correspondence author) \\ Professor of Finance, Finance, Real Estate \& Law Department \\ California State Polytechnic University \\ 3801 W Temple Ave, Pomona, CA 91768, USA \\ Tel: 909-869-4524Ｅ-mail: mmuhtaseb@cpp.edu
}

Received: August 6, 2018 Accepted: September 18, 2018 Published: September 25, 2018

doi:10.5296/ijafr.v8i3.13699

URL: https://doi.org/10.5296/ijafr.v8i3.13699

\begin{abstract}
In November 2015, the International Monetary Fund (IMF) decided to add Islamic finance to its monitoring of financial sectors around the world. The IMF traditionally has focused on conventional banking but recently it has become interested in Islamic banking and finance due to its phenomenal growth. Islamic banking assets exceed $\$ 2$ trillion globally. This decision of the IMF has brought tremendous opportunity for Islamic banking constituents all over the world. However, many practitioners and supervisory authorities may not be aware of the fundamental differences between Islamic and conventional banking. This paper attempts to identify the major differences between the Conventional and Islamic Banking, and discuss the challenges of integrating Islamic banking and finance into the global financial markets.
\end{abstract}

Keywords: Islamic banking, Sharia, Riba, Mudarabah, Musharakah, Murabaha

\section{Introduction}

Commercial banking as a form of financial intermediation plays a major role in mobilizing of funds among different sectors of economy around the world. In a conventional monetary system, fiat money serves as a medium of exchange and store of value. Funds of surplus spending units (households, firms, and government) are transferred directly or indirectly within different sectors of economy to the deficit spending units. This process of mobilizing funds allows the deficit spending units to pursue and fulfill their investment projects which in 
turn lead to economic growth. This process is facilitated by a market determined cost of funds, the rate of interest, which borrowers are obligated to pay to lenders during the term of the loan.

On the other hand, Islamic banking refers to a banking system that operates under the principles of Sharia (Islamic laws). Under this law, all Islamic financial transactions must be free from the following:

1. The payment or acceptance of interest (riba)

2. Trading under uncertainty (gharar) in financial transactions. Sharia defines gharar as a situation whose consequences are hidden or unknown. Speculation and gambling are forbidden.

3. Under Islamic law, money is not an asset; it is merely a medium of exchange and a measuring unit of account. An individual or an institution should not be able to generate money from money. This self-generation of money from money is riba.

4. Any transactions (buying, selling, and distribution) that involve alcoholic beverages, pork, prohibited drugs, gambling, pornography, and weapons (Afshar, 2013, pp.44-45).

The main sources of Sharia rules come from the Quran, which also includes God's messages in both Torah and the Gospel; the recorded quotes (Hadeeth) and example of living (Sunnah) of the Prophet Mohammad (peace be upon Him) (Abdul-Rahman, 2010, p.84). All Shariah complaint transactions must adhere to the ethical principles and practices promulgated by the holy books.

There are major differences between conventional and Islamic finance that are both ethical as well as technical (Khair Bakhsh, 2011, p.1). The ethical differences are related to the ownership of wealth (assets). In Islam, ownership of wealth exclusively belongs to the God Almighty. The focus of Islam is on the social and moral responsibility of investors while in possession and control of assets. Islam forbids the concentration of wealth in the hands of a few. This invokes a spiritual element in financial transactions. The technical (legal and operational) differences between conventional and Islamic finance are substantial. This leads us to introduce the unique features of the Islamic Banking.

\section{A Brief Description of the Key Features of Islamic Banking}

In Islamic banking (IB), a financial institution serves not only a financial intermediary but also a custodian (Mudarib) and a fund or asset manager. Unlike in traditional commercial banking, a financial institution plays an active role in the transaction, much more than simply intermediating. The profits and losses are shared among the parties equitably and proportionately, rather than a financial institution earning spread between the interest rate charged and the interest rate paid, as in conventional banking system (CB). However, in the IB system, there is no interest to be split between bank and depositors. Indeed Sharia prohibits the paying and receiving of interest charges (Riba) while borrowing and lending of money as well as in other IB operations.

In IB system, money is a medium of exchange; it is not commodity with a price for its use. Hence, Islamic Banking system fosters an environment conducive to stability in the value of money (currency) and allows the medium of exchange to be more reliable unit of account. In 
a CB system, the price of money is the interest rate. Should the interest rate on a currency change, its value against other currencies will fluctuate in response.

Islamic banking distinguishes between the time value of money as a measure of investment efficiency (part of the reward for investors) and the determinants of the rate of return (yield) on an investment. In IB transactions, the two parties do not commit to a predetermined rate on a loan. The rates of returns are either based upon profit and loss sharing in the business and/or negotiated price in sale or lease transactions.

In an IB system all of the financial needs of businesses, including those of entrepreneurs are serviced by financial institutions through their direct participation in completion of the pre-approved Sharia complaint project. The IB relies on profit- loss- sharing (PLS) scheme, as opposed to cost of funds (interest rate) scheme. These participatory financing structures (details will be discussed under IB's Use of Funds Section) are a unique and a positive contribution of Islamic Banking to Conventional Banking in which both funds provider (Islamic financial institution) and the borrower together complete a Sharia complaint project.

Depositors in IB system are owners of the fund (Arbabul Mal) and are not bondholders or creditors. They are investors and potentially are exposed to lose their deposit (capital). They may experience substantial loss if the underlying project fails, no matter how much bank mitigates the risks to which they are exposed. The depositor's capital (effectively investment in the project) is ultimately at risk, even if the bank remains solvent and profitable.

In IB system depositors are financial investors bound by a de-facto partnership contract (Mudarabah) between IB institution and depositors. In the process of financing projects, an Islamic bank plays a Mudarib who acts as either fund manager or business manager on behalf of depositors. An IB customer, willing to invest in a Sharia compliant project on a Mudarib basis, enters into a Mudarabah agreement with IB. The latter acts as Arbabul Mal (an investor who provides the capital). The customer acts as Mudarib (an enterprise who gives their expertise to accomplish the project).

Depositors as financial investors have an absolute right to receive information and to monitor investment activities. The investors' rights are normally negotiated in advance and defined in the investment and financing agreement. In IB system all losses are borne by depositors (Arababul Mal) unless Mudarib (business manager who executes the sharia complaint project) has been negligent. In which case the Mudarib normally assumes the loss.

The project's profit (if any) is distributed among the two parties: Arbabul Mal (depositors) and Mudarib (IB institution, customer, or third party, who acts as business manager). Profits are distributed according to a predefined ratio between 2 parties in the Mudarabah agreement. The following rules are used to share the profit:

a. Depositors share of profits $=$ Total profit (if any) generated from the implementing the project less Mudarib's fee.

b. Mudarib's fee is a predetermined (agreed) upon amount or formula.

c. Share of profit of IB's shareholders is the profit or loss of the institution (Mudarib) plus the Mudarib fee. 


\section{MlMacrothink}

International Journal of Accounting and Financial Reporting

ISSN 2162-3082

2018, Vol. 8, No. 3

Investors (depositors) in IB system receive Mudaribah certificate (investment deposit certificate) in exchange for their deposits. Mudarabah contract is frequently applied to the syndication of large Islamic transactions involving many banks and investors.

Most IB intuitions acting as Mudarib hold profit equalization reserves that allow the institution to smooth income over reporting periods so as to generate a more stable and consistent level of profitability for investors. These reserves are taken out of the Mudarabah income, before allocating the share of the Mudarib to the benefit of the holders of the investment accounts. Management of the bank decides what a prudent allocation of funds is. This helps IB institutions compete against conventional (interest rate based) banks when market conditions require them to pay higher interest rates.

In IB system, borrowers do not receive cash directly from bank to fulfill their project's financial needs, rather the IB completes the customer's project entirely in line with the active role that the IB institution plays as described earlier.

\section{Sources and Uses of Funds of Institutions in IB System}

The primary difference among depository (IB and CB) institutions is in the composition of their asset (loan) portfolio. This section covers the sources and uses of funds of IB. Table 1 lists the sources and uses of an IB institution.

Table 1. Islamic banking institution sources and uses

\begin{tabular}{ll}
\hline SOURCES OF FUNDS: & USES OF FUNDS \\
\hline Clients Account: & Domestic \& International Financing: \\
-Current account & -Musharakah (Joint Venture) \\
-Saving account & -Mudarabah \\
-Investment account & -Murabaha \\
\hline Shareholder Funds: & -Trade financing \\
-Share capital & -No-cost loans (Domestic) \\
-Reserves & Loans with service charge \\
\hline Other Funds: & \\
-Off Balance Sheet & \\
\hline
\end{tabular}

Sources of Funds:

Customers' deposits are the main source of funds at banks. Banks strive to find various ways to entice their customers to deposit their savings. Some banks my offer monetary or non-monetary rewards. Others may offer exemption from or reduction of paying fees for transactions with the banks. There are three types of deposit accounts offered by Islamic Banks:

1) Current accounts: These are similar to checking accounts in $C B$ institutions in which client is allowed to periodically withdraw any amount up to balance in the account and also deposit additional amounts. In this type of account, the capital (deposit) is guaranteed and depositors do not receive any profit. 


\section{Mll Macrothink}

International Journal of Accounting and Financial Reporting

ISSN 2162-3082

2018, Vol. 8, No. 3

2) Savings accounts: This account operates in two different ways. i) Depositors allow the banks to use their money with a guarantee that deposit will be paid back in full but no profit is promised, like a current account. ii) Savings account is treated as if it were an investment account but with stringent terms on withdrawals and a minimum balance requirement. Capital is not guaranteed but banks invest these funds in low risk short- term projects that yield lower rates. As such lower profit rates are expected and that too only a portion of the average minimum balance needs to be kept at all times to meet withdrawal restrictions. (A.L.M. Abdul Gafoor, 1995, Ch.4: Interest Free Commercial Banking).

3) Investment Accounts: Investment deposits are kept in IB institution for short or long periods. Depositors agree to enter into the Sharia compliant contracts with the bank in order to undertake a Sharia compliant project. Capital is not guaranteed and profit and loss (PLS) is shared between bank and depositors based on pre-approved agreement.

Table 2. Sources and uses of funds at commercial banks

\begin{tabular}{ll}
\hline SOURCES OF FUNDS: & USES OF FUNDS \\
\hline Clients Account: & Loans \\
-Demand Deposits & -Real Estate Loan \\
-All NOW and ATS Account & -Commercial Loans \\
-Money market Deposit Account & -Individual Loans \\
-Other Saving Deposits & -Agricultural Loans \\
-Time Deposits & Investments: \\
TOTAL DEPOSITS & -U.S. Treasury and Agency Securities \\
Long-term debt & -Municipal Securities \\
& -Foreign Debt Securities \\
& -All Others \\
\hline
\end{tabular}

\section{Equity}

-All Common

-Preferred Capital

\section{Other Funds: \\ Loans with service charge}

-Fed Funds (Purchase and Resale)

\section{Uses of Funds:}

In order for Islamic bank's customers to fully comply with Sharia requirements, Islamic banks have developed a range of products for customers and investors. Among these products are musharakah, mudarabah, murabaha, trade financing, no-cost loans, loans with a service charge.

\section{1) Musharakah}

It is joint venture model normally applied to a business partnership and it is essentially a sharing model. All assets of Musharakah are jointly owned by all partners based on pro rata basis. Partners of Musharakah are exposed to unlimited liability incurred in operating the 
underlying project. The parties involved share profits or losses from the underlying project based on an agreement. These partnerships are Sharia compliant contracts. The members of Musharakah appoint one or more of them or a third party, non-member to manage Musharakah.

In order to mitigate any losses, the constructive liquidation ensues through which the enterprise is not terminated, rather a member withdraws or sells his/her position.

As a rule, a Musharakah may not be dissolved without the knowledge and consent of all its members. Most Islamic scholars agree that the formal process of a bankruptcy notice fulfills this obligation.

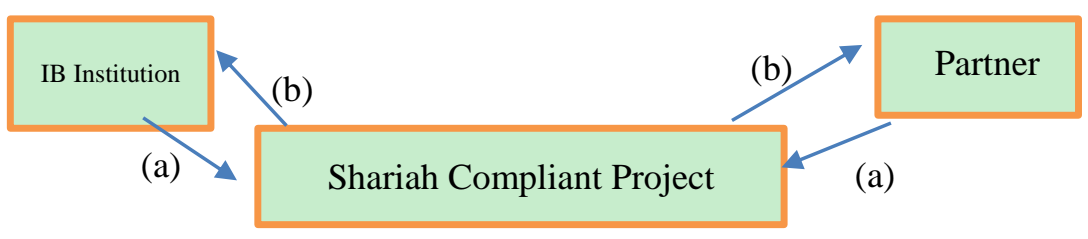

Figure 1. Musharakah transaction structure

a. Funds and Expertise: Both IB Institution and Client provide funds and expertise.

b. Profit/Loss Sharing: Both IB Institution and Client share in Profit/Loss.

Both IB institution and Business Partner provide funds and expertise and share in profits and losses, similar to legal partnership structure.

2) Mudarabah

Under this contract the owner of capital invests the funds and other party (Mudarib) supplies the expertise for the project. Through its management and expertise the Mudarib is responsible for implementing and supervising the project. The two parties agree on how the profits are to be divided. The profit share allocations must be based on actual profit earned by the project. Sharia does not restrict or specify how profit should be distributed. It leaves it to the judgement and negotiation of two parties. (Durchslag, et.al, p. 151).

However, there may be some problems in successfully implementing a Mudarabah contract that uses the profit and loss scheme. The fund provider relies completely on the honesty and integrity of the Mudarib. It has been reported in some countries that the Mudarib (agent) in some cases has declared a loss when it actually made a profit. Undoubtedly in Mudarabah investors are exposed to operational risk, most notably fraud, to a greater extent than under other structures.

According to the pre-agreed upon terms in this contract, any losses are solely borne by the investor, that is IB institution. The only exception is when the Mudarib (agent) has been negligent, at which time the entire losses are borne by the agent. Even if there is a significant possibility of any negligence, usually it is hard to prove it in the court of some Islamic countries.

The other problem in implementing the profit and loss sharing scheme is in arranging government loans, where projects are not based on profits. The other problem is the lack of skilled professionals who can evaluate the feasibility of the Sharia compliant projects that are proposed by the Mudarib and agreed upon by both parties. 


\section{MInstitute ${ }^{\text {Min }}$}

International Journal of Accounting and Financial Reporting

ISSN 2162-3082

2018, Vol. 8, No. 3

Under Mudarabah, an IB institution serving as a financial investor has an absolute right to receive information and to monitor investment activities. These kind of rights and obligations are similar to a limited partnership company structure.

For an Islamic Bank, Mudarabah contract is the cornerstone of financial intermediation. The basic concept is that both fund mobilization from one sector to another and use of funds are based on some form of profit and risk sharing among depositors, the bank, and the entrepreneurs. In practice many Sharia scholars usually advise IB institution to invest part of the share holders' funds together with the depositors' funds (Rabul Mal) in the structuring of Mudarabah contract. Figure 2 summarizes a typical mudarabah transaction.

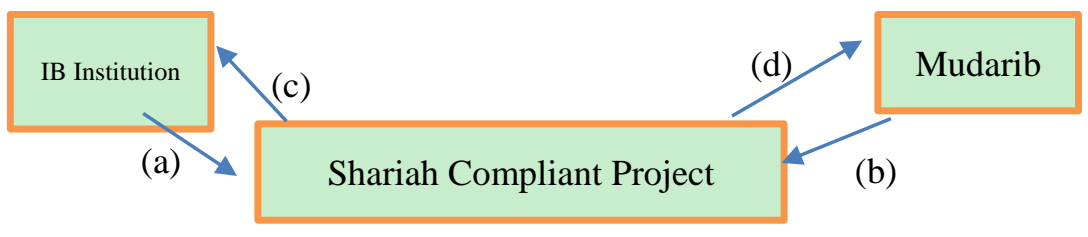

Figure 2. Mudarabah transaction structure

a. IB institution provides all of the funds

b. Mudarib provides expertise (usually no funds)

c. If project is profitable, IB institution shares in profit. Yet if underlying project incurs losses, all losses are borne by IB institution.

d. If project is profitable Mudarib shares in profit.

Mudarib incurs a loss only when the loss occurs due to Mudarib's negligence. In essence Mudarib exposure to business risk is minimal.

"Commenting on Mudarabah financing, the Economist says: ... some people in the West have begun to find the idea attractive. It gives the provider of money a strong incentive to be sure he is doing something sensible with it. What a pity the West's banks did not have that incentive in so many of their lending decisions in the 1970s and 1980s. It also emphasizes the sharing of responsibility, by all users of money. That helps to make the free-market system more open; you might say more democratic." (Islamic Banking by A.L.M. Gafoor, p.17, 1995)

\section{3) Murabaha}

Under this contract Islamic institution buys the asset then immediately sells it to the customer (the borrower at a commercial bank) at a higher price that was previously agree upon. It is a cost plus transaction and usually used when a bank purchases a customer's choice of a property. Under this contract, the price of the asset is set at a level that takes into account the term-to maturity of the agreement. The customer's monthly payments cover pre-agreed price plus IB institution's profit. (Durchslag, et.al p.127)

When Murabaha is executed as an installment credit sale, the closing date must be definite. The payment in Murabaha may be made on a spot or deferred basis. Collateral, in the form of a registered lien or mortgage, is permissible. In the event of late payment, the seller usually the bank may not apply a late payment fee or penalty charge. If a bank decides to charge 
penalty, any amount over and above the original required payment will have to be donated to charity.

To mitigate nonperformance risk, IB institution requires the buyer (the borrower) to sign an agreement unilaterally promising to purchase goods from the IB institution. In the USA and the UK, a promise to buy document is sufficient.

A variation of the plain vanilla Murabaha is the Commodity Murabaha. It is a deferred payment sale or installment credit sale and uses a commodity, usually a base metal as underlying asset for the transaction. The price of commodity, the mark up and the delivery date are clearly spelled out in the contract upon agreement. The metals are purchased and sold solely to facilitate interbank liquidity in accordance with Sharia principles. Through this structure, an IB institution either provides short-term interbank liquidity or facilitates short-term trade transactions.

Commodity as underlying asset has to be non-perishable, reasonably abundant and uniquely identifiable. The majority of commodity Murabaha transactions use London Metal Exchange (Schoon, Natalie, 2009, p. 111).

\section{4) Trade Financing}

There are three forms of Sharia complaint trade financing arrangements. These are: a) mark-up where the bank buys an item for a client and the client agrees to repay the bank the price plus an agreed profit at a later date; b) Leasing (Ijara), where the bank buys an item for a client and leases it to client for an agreed period at the end of which the lessee pays the balance on the price previously agreed upon which is higher than original price. c) Istisna is a Sharia mode of financing to finance the construction of buildings, aircrafts, ships machines, etc. It is a sale contract between the seller and the buyer in which the seller is ordered to produce a specific commodity or equipment for the buyer. The price must be determined at the initiation of contract, and offer and acceptance must be made at the same meeting. The settlement of payment under this contract could be to pay total price at the time of execution of contract, or delivery time, or pay on an installment basis as agreed upon between the seller and the buyer (Islamic Banking and Finance in Malaysia, pp.143-145)

\section{5) No-cost loans}

In many Islamic finance jurisdictions, every IB institution is required to set aside a portion of its deposits, basically on a pro bono basis, to the enterprising and needy individuals or businesses. These loans are called Qard-ul-hasan which allow borrowers to meet their essential needs such as marriage expenses, medical expenses and educational expenses. They can also be used to help small businesses launch or expand their lines of business, especially in agriculture, livestock, and industrial products. These no-cost loans are also sometimes used to assist with housing costs. The funds for these loans are provided by IB institution's benevolent customers (depositors) who wish to gain rewards from the almighty God.

This is the only type of the IB institution's loan which is paid in cash. This loan carries a small amount of fee and is payable by borrowers. However, these fees are not considered as income for the IB institution. There is no penalty for late payment. At times IB institution's 
depositors may forgive the entire loan or the remaining portion of the loan in case the borrower is unable to repay.

\section{6) Loans with a Service Charge}

These loans were introduced into the IB system as a simple solution to improve the difficulties that arise in practical implementation of the PLS scheme. This scheme is adopted by an IB institution in order to avoid paying or receiving interest (Riba); a forbidden practice in Islam. According to Abdul Gafoor (1995), there are four primary financing arrangement where an IB institution encounters difficulty in implementing the PLS scheme. These four are:1) participating in long-term low yield projects, 2) financing the small businessman, 3) granting non-participating loans to running business, and 4) financing government borrowing.

On the other hand, loans with service charge allows depositors to receive a guaranteed rate of return whose magnitude is proportional to the term of the loan and amount of the loan. The depositors are guaranteed to get their capital at maturity, as in conventional banking system. This type of loan is popular mostly in Iran and Pakistan.

\section{What Are Those Challenges?}

In spite of the rich history and profound impact of Islamic Banking in many parts of the world, there are still some challenges that stakeholders worldwide will have to surmount over time.

1. The sharia is the interpretation of Quran, Hadeeth, and Sunnah. However, the Sharia interpretations and applications could be quite different from one country to another or from one sect of the religion to another and even from one school of thought to another. As a result, a product could be permissible in one IB institution, while the same product may not be allowed in another institution, possibly even in the same city. This may create confusion for the near future until Sharia standards are developed and harmonized for the global Islamic financial market.

2. Maintaining public confidence that supports continuous financial intermediation is necessary for effective implementation of financial safety of Islamic banking. Many people in the Muslim and non-Muslim regions do not understand Islamic banking. There is no formal or standard definition of what is or in not IB, an Islamic-banking product, or service. The Sharia Councils or Boards at individual Islamic banks all over the world have a responsibility to educate people and show them what is, or is not the acceptable way to execute Sharia based business transactions. The public should be properly advised that Islamic bank operates within the boundaries of principles of Sharia where in essence there is no room for Riba (usury). (Islamic Banking: Problem and Prospects, p.4).

3. The third challenge for Islamic banking in the global market is in the absence of a formal Sharia compliant financial market worldwide (The IMF \& Islam, p.4) and the accompanying requisite uniform accounting, auditing, and compliance standards. Competition and conflicts among different jurisdictions could restrain economic growth and evoke instability.

4. The absence of such market hinders the secondary market transactions of Islamic products for both Islamic banks as well as investors. Many IBs do not have access to the liquidity instruments such as Treasury bills and other marketable securities. "This problem is 
aggravated since many Islamic banks work under operational procedures different from those of central banks; the resulting non-compatibility prevents the central banks from controlling or giving support to Islamic banks if a liquidity gap should occur."(Islamic Banking: Problems and Prospects, p. 5). The absence of an Islamic money market impedes IB institutions from investing their temporary excess liquidity to earn any income rather than keeping it idle. Hence, the liquidity management should be considered as one of the most important and serious issues in operating an IB institution globally.

5. Another key challenge for Islamic banking is ability to attract and maintain a knowledge rich workforce who are educated and trained to enhance the potential for innovation, productivity, and performance. In addition, these specialists would need to understand the Sharia and its application. There is a need to institute consistent professionalism in Islamic banking practices. "Most banks' professionals have been trained in conventional economics. They lack the requisite vision and conviction about the efficiency of the Islamic banking" (Irbid, p.5).

6. Many Islamic banks do not have the diversity of products essential to satisfy the growing needs of their clients. This is because most IB's professional are not adequately familiar with modern financial techniques to be able to operate and survive in an intensively competitive environment and sophisticated global markets and informed public. Thus, one of the urgent challenges of IB in global market should be establishing an ongoing advanced technology and media to train their personnel to be able to effectively compete with conventional banking.

7. Many IB institutions are often times unable and/or unwilling to participate in long-term projects for several reasons: 1) they may require specialized expertise and experience along with extensive and time-consuming research and analysis. 2) Capital is tied up for very long term. The longer term of these projects forces a longer investment horizon upon the institution and the expected returns. As a result, IB institutions are not in a solid position to distribute profits in the short and intermediate term, to their depositors, as the conventional banks are (Ibid, P.21). The source of funds for these long-term loans are saving accounts in IB system, where IB depositors are not guaranteed to get their capital back intact as well as they are not promised a certain return. However, both capital and rate of return on saving accounts are guaranteed in the CB system. These issues pose serious challenges to the IB system in terms of its ability to compete with the $\mathrm{CB}$ in the global financial market.

8. The Islamic banking intuitions faces competition from Non- Islamic commercial banks for customers, services and investment returns. This could ultimately affect the long run viability of some IB institutions. Interestingly the IMF study indicates that "the rate of return on retail Islamic investment accounts closely follows the behavior of interest rates provided by commercial banks" (IMF Working Paper, July 2011). Most Islamic banks hold reserves that enable them to maintain certain consistent levels of profitability over time, for their investors. These reserves act as profit equalization reserve. This helps Islamic Banking compete against conventional banks when the latter raises their interest rates.

9. Diversification is a major venue for managing the market risk of an investment portfolio. Due to Sharia compliance requirements, the fund manager of an IB's investment portfolio is 
obliged to invest in narrow sector of the market. In IB transactions, the depositors are exposed to gains as well as losses, unlike the holders of a checking account at a CB institution, who effectively are exposed to entire bank's assets risks and hence more diversified.

10. Many practitioners employ derivatives to reduce or eliminate the risk of a portfolio or an asset. The Sharia scholars have, for the most part prohibited investment in derivatives, at least for speculative purposes. On the other hand, some Sharia scholars believed that there exist certain Sharia compliant derivatives that can be used for risk management and hence to protect against potentially adverse market conditions. Therefore, there is a great likelihood that some scholars and Islamic financial institutions will develop Sharia compliant derivatives.

11. According to Reuters, In May 2018, the IMF decided to include IB institutions in its monitoring of the financial sector worldwide. Islamic Financial Services Board (IFSB) of Malaysia issued the guidance for the IMF for regulating and supervising Islamic banks. This reflects the fast growth of IB assets and greater role IB intuitions have in many countries. IB institutions are structurally different from CBs. The IMF would have to overcome a learning curve on how IB institutions operate in order to develop the appropriate monitoring, supervisory and regulatory processes along with qualified professional staff.

\section{Summary and Conclusions}

In 2015, the IMF decided to include Islamic banking and finance into its monitoring of the global financial sector. Delightfully the IMF rolled out the welcome mat for Islamic institutions yet there are challenges that could take some time to overcome. This allows IBIs to contribute as a parallel banking system that also operates increasingly globally. IB offers a wide variety of banking products that are asset based and comply with the sharia. "According to an IMF study, the institutions that were least affected by the global financial crisis were Islamic banks because they mainly engage in asset- based financing."

An IB avoids using interest (riba) in its operations and provides similar level of return as compared with conventional banking. Due to prohibition of interest, Islamic Banks cannot issue debt (in the western banking sense) to finance assets which leads to no financial leverage. Due to absence of leverage that imposes interest payments on borrower regardless of economic conditions, the Islamic Banks tend to be less risky than conventional banks. In 2009 , the official newspaper of the Vatican put forward the idea that "the ethical principles on which Islamic finance is based may bring banks closer to their clients and to the true spirit which should mark every financial service." Normally ethical conduct is a professional standard that practicing professionals are expected to rise up to. Within Islamic banking, invoking morality is required and hence an integral component of all financing and investment decisions.

Islamic Banking introduces the Profit Loss Sharing scheme as a device to eliminate interest (riba) and asymmetry of payoffs from financial transaction through using various Sharia compliant contracts. In this paper we presented only a few of the most popular Islamic financing structures. These contracts allow IBIs, their depositors (fund providers), and 
entrepreneurs (borrowers) to jointly participate in executing Sharia compliant projects that will be beneficial to mankind and facilitate the sharing of profits (losses) to affected parties.

In order to overcome the challenges of further integrating Islamic finance in global markets, the global financial community needs to pursue several far reaching initiatives. There is an urgent need for uniform consistent location invariant interpretation of Quran, Hadeeth, and Sunnah. The growth of Islamic finance is hampered by the absence of yet to emerge a fully integrated global financial market that applies uniform auditing, accounting and compliance standards. The Accounting and Auditing Organization for Islamic Financial Institutions (AAOIFI) is definitely one excellent step in the right direction.

Maintaining the confidence of the public (muslim and non muslim) requires extensive outreach and education of the public in numerous parts of the world. It is of utmost importance for IBIs to launch a formal Sharia compliant secondary financial market worldwide and the accompanying requisite uniform accounting, auditing, corporate governance requirements and compliance standards. Within this integrated market, liquidly is facilitated and cost of capital is reduced. IBIs will be in a better position to offer many new products and services, reduce portfolio risk and more effectively compete with conventional banks. Through he integrated global market, IBIs will be in a stronger financial and operational position to commit funds for long-term projects.

Banking and finance professionals employ derivatives to reduce or eliminate the risk of a portfolio or an asset. The Sharia scholars have, for the most part prohibited investment in derivatives, at least for speculative purposes. What is urgently needed is advances in our understanding of how derivatives can be Shariah compliant. We still have a lot to learn about how derivatives can be applied by IBIs.

Above all, in the spirit of the first word revealed in the Quran, "Read (or Recite)" Islamic banking and the global finance profession recognized the need to attract and maintain a knowledge rich workforce who are educated and trained in conventional and Islamic finance. This can only be accomplished by investing in human capital. Long term the industry shall benefit from greater innovation, productivity, and performance.

\section{References}

Abdul-Rahman, Y. (2014). The Art of Islamic Banking and Finance, Tools \&Techniques for Community-Based Banking (2nd ed.). Wiley.

Afshar, T. (2013, February). Compare and Contrast Sukuk (Islamic Bonds) with Conventional Bonds, Are They Compatible?. Journal of Global Business Management, 9(1), 44-52.

Aziz, M. R. Ab. (2013). Islamic Banking and Finance in Malaysia: System, Issues and Challenges. USIM Publisher, Bandar Baru Niali, Negeri Sembilan.

Bakhsh, K. (2008, March 15). Expanding the Islamic Banking System. Retrieved from www.helium.com

Cevik, S., \& Charap, J. (2011). The Behavior of Conventional and Islamic Bank Deposit Returns in Malaysia and Turkey. IMF Working Paper, pp.1-23. 


\section{Macrothink}

International Journal of Accounting and Financial Reporting ISSN 2162-3082

Durchslag, A. (2010). Islamic Finance Instruments and Markets. Bloomsbury Information Ltd, UK.

Gafoor, A. (1995). ALM Islamic Banking, Chapter 4. Retrieved from http://users.bart.nl/ abdul/chap4.html

Hannan, S. A. (n.d.) Islamic Banking: Problems and Prospects, pp. 1-7. Retrieved from http://shahfoundationbd.org/hannan/article10.html

Haqiqi. (2010, June). Challenges of Islamic banking, pp. 1-24. Retrieved from http://www.slideshare.net/alhuudacibe

IMF. (2015, March). Islamic Finance and the Role of the IMF. Retrieved from http://www.imf.org/external/themes/islamic finance/index.htm

Norat, M., Pinon, M., \& Zeidane, Z. (2015, April 5). The promise of Islamic Finance: Further inclusion with Stability. Retrieved from https://blog-imfdirect.imf.org/2015/04/06/the-promise-of-islamic-finance-further-inclusion-w ith-stability/

The central Bank of Lebanon. (n. d.). Islamic Finance Qualifications. Retrieved from http://www.bdl.gov.lb/laws/index/5/32/Laws.html

Vizcaino, B. (2015, November 11). IMF to Include Islamic Finance in Surveillance -Lagarde. Reuters. Thomson Reuters. Retrieved from http://www.reuters.com/article/2015/11/11/imf-islamfinancing-idUSL8N12Zo4N201511\#0O 0qsH56XF73fMdS

Vizcaino, B. (2019, May 24). IMF to Include Islamic Finance in Surveillance in 2019 -Lagarde. Reuters. Thomson Reuters. Retrieved from https://www.reuters.com/article/us-islamic-finance-imf/imf-to-add-islamic-finance-to-market -surveillance-in-2019-idUSKCN1IQ081

World Bulletin. (2009, March 6). Vatican offers Islamic finance system to Western Banks.

\section{Copyright Disclaimer}

Copyright for this article is retained by the author(s), with first publication rights granted to the journal.

This is an open-access article distributed under the terms and conditions of the Creative Commons Attribution license (http://creativecommons.org/licenses/by/4.0/) 